\title{
Socioecological Aspects of High-rise Construction
}

\author{
Michael ' Eichner $^{1 *}$ and Zinaida Ivanova ${ }^{2}$ \\ ${ }^{1}$ German University in Cairo - GUC, New Cairo City - Main Entrance of Al Tagamoa Al Khames, \\ Egypt \\ ${ }^{2}$ Moscow State University of Civil Engineering, Yaroslavskoe shosse, 26, Moscow, 129337, Russia
}

\begin{abstract}
In this article, the authors consider the socioecological problems that arise in the construction and operation of high-rise buildings. They study different points of view on high-rise construction and note that the approaches to this problem are very different. They also analyse projects of modern architects and which attempts are made to overcome negative impacts on nature and mankind. The article contains materials of sociological research, confirming the ambivalent attitude of urban population to high-rise buildings. In addition, one of the author's sociological survey reveals the level of environmental preparedness of the university students, studying in the field of "Construction of unique buildings and structures", raising the question of how future specialists are ready to take into account socioecological problems. Conclusion of the authors: the construction of high-rise buildings is associated with huge social and environmental risks, negative impact on the biosphere and human health. This requires deepened skills about sustainable design methods and environmental friendly construction technologies of future specialists. Professor M. Eichner presents in the article his case study project results on implementation of holistic eco-sustainable construction principles for mixed-use high-rise building in the metropolis of Cairo.
\end{abstract}

\section{Introduction}

Social and environmental problems of high-rise construction are more and more discussed in relation with the growing number of high-rise buildings and the expansion of their functional purpose and urban presence. In different countries there are different approaches to determining the number of floors of high-rise buildings. According to Russian building codes, buildings that rise from 75 meters (public objects from 50) to 120-150 meters, with the number of floors not exceeding 30, are classified as high-rise buildings. All buildings higher than this are usually called super-high buildings or skyscrapers. Tower buildings are mostly multifunctional, accommodating offices (International Business Centre, Seul), banks, stock exchanges (Taipei Financial Centre, Taiwan), hotels and casinos (Las-Vegas), apartments (Moscow City), educational buildings (Moscow, MGU). There are high-rise apartment buildings, such as the well-known residential complexes "House on

*Corresponding authors: ivanovazi@mail.ru 
Mosfilmovskaya" in Moscow, the "Aqua Tower" in Chicago or the "Bosco Verticale" in Milano. If high-rise constructions were considered to contribute economic and innovative value, they are also responsible for many social and urban problems, changing the faces and atmosphere of cities and can have negative impact on the public live, city infrastructure, the environment and living quality in cities. During last decades these implications became more acute, as the number of storeys of buildings grew, their number increased, with over densification of city centres and over forming former low-rise districts of established quarters with out of scale point constructions.

Today, the attitude towards high-rise construction is ambivalent. There are supporters and opponents of tall buildings, both among specialists, architects, builders and residents.

\section{Literature Review}

Works devoted to the development of architectural typology and the history of high-rise buildings are manifold. The first works appeared in the second half of the twentieth century. In particular most works, published at that time, the history of the formation of various types of high-rise buildings was examined [1] and their constructive and technological evolution [2]. The dispute between supporters of high-rise constructions and opponents was controversial discussed in the press, scientific conferences and public hearings during the second half of the twentieth century. Some authors believed, that multi-storey construction is the bright future of buildings, helping to solve problems that are associated with the growth of the population of cities. Today, more than half of the world's population lives in cities. This figure will soon approach in Europe $85 \%$ and in Russia 74\% [3]. Land is becoming more expensive in cities, with one square meter of land in the historical centre of Moscow of average 21,000 rubbles. This price varies from 15,800 to 18,836 rubbles in different parts of the capital [4]. The rise in land prices is the main reason for the construction of high-rise buildings, according to some authors. [5]. Other researchers object this argument and call the rise in land prices a secondary factor. They put forward the desire of architects, town planners, city authorities to build something that stands out, which would become a symbol of the city and surpasses the height of buildings in other cities. In other words, the problems of the development of high-rise buildings and their architecture can not only be seen in relation to social or technical needs, but also in the auspicious images of high-rise towers and their possibility to create an accent in cities, raising their status among the world's cities by displaying advances in architecture and technology [6,7]. Tall buildings become symbols of technological progress, prestige and define the face of cities.

Equally important is the economic side of high-rise construction: the majority of highrise buildings are commercial with high economic and profit advantages, as more square meters can be built on a smaller site areas, generating higher leased for offices [6]. The subsequent high costs of operation will be compensated by higher rents, achieved.

The attitude of different authors to the complex problems of designing and maintaining technical systems like communication, ventilation, technical operation, fire safety of high building structures is also ambiguous. Problems like aerodynamics, big ventilation shaft areas per floor, complicated heating and control systems inevitably arise during construction and operation and require high planning and construction effort. From this point of view, highrise buildings should be "smart" and "low-tech", minimizing necessary technical systems and following the idea of "bioclimatic architecture" in areas with complex climatic conditions $[8,9]$. Social and environmental aspects of high-rise constructions are the most controversial. According to some Russian authors, "today, high-rise construction is perceived and evaluated by the population extremely negatively, rejected as a disharmonious and ugly creation of a technocratic civilization, that is aggressive and hostile to the centuries-old historic cities" [5]. Other Russian authors believe, that in the next 10 years skyscrapers will account for up to 
$7 \%$ of the total annually newly built area of Moscow's apartments, since many Muscovites would like to live in high-rise buildings [10]. The academic of the Russian Academy of Architecture and Building Sciences Yu.P. Grigoriev, former deputy chief architect of Moscow holds a special point of view. In his opinion, high-rise construction should not at all be residential (residential development should be within 9-12 floors), despite the fact that it is profitable to build high-rise residential buildings [11].

\section{Research problem and objectives}

The purpose of this article is to identify socio-ecologic problems of high-rise architecture, problems that affect physical and psychological conditions including the well being of people, giving them a feeling of comfort or discomfort. These problems were examined by interviewing inhabitants of high-rises to find out, which negative consequences follow the construction of high-rises. The article uses the results of a sociological survey of Muscovites and polls, conducted at the National Research Moscow State University of Civil Engineering. Respondents were students, studying in the field of "Construction of unique buildings and structures" (high-rise construction). The surveys were conducted in November 2016 and November 2017. In addition, methodological analysis of scientific conference publications and public hearing materials was conducted, including interviews with experts, government officials to analyse opinions of various social groups. The second author of the article, Professor M. Eichner carried out a case study research project on the possibilities to enhance high rise architecture of mixed-use housing complexes by a comprehensive implementation of sustainable housing standards during the design phase of projects, to find out, whether in capital cities of developing countries these instruments can minimize harmful influences on the biosphere and enhance habitat condition of inhabitants of tall buildings in metropole cities.

\section{Results}

\subsection{Socio-ecological problems of high-rise architecture}

Socio-ecologic aspects of high-rise buildings and vertical districts characterize the level of comfort and safety of people in buildings and the quality of the surrounding environment.

\subsubsection{Ensuring the safety of high-rise building users}

Increased effort is necessary to ensure convenient and save inside space conditions, balanced room temperature, air quality, acoustics, hygienic factors, water supply and sanitation in high-rise buildings for residential, hotel, office purposes. Uninterrupted operation of elevators is essential in order to ensure the movement of passengers "up and down" in a regulatory regime, limiting the waiting time of elevators according norms, with waiting times not interrupting the functional rhythm of the building. High-rise buildings are often equipped with high-speed elevators, which have reached a high technological level but are contraindicated in some cases for passengers with certain diseases.

Security problems are manifold and also related to engineering systems. Modern highrise buildings are equipped with mechanical ventilation systems, which have to be protected of fire and smoke distribution but at the same time against terrorist acts with poisonous substances at air intake devices. The probability of death of a large number of people is higher in comparison to low rise buildings in case of natural catastrophes. The authorities of Macon County (North Carolina, USA) announced in December 2006 an 11-month moratorium on 
issuing permits for high-rise constructions. They argued this prohibition by the fact, that highrise buildings have a larger population density and, consequently, a greater risk of death and injury of people during natural disasters [12].

Urban integration of tall buildings and security issues are directly related. Modern cities, especially metropole cities, are highly equipped with underground communication systems and infrastructure, different geological formations, landslide threats, which creates the danger of subsidence and destruction of buildings. In addition, the absence of strong winds and seismic danger, minimum humidity and good load-bearing capacity of the soil are required, raising issues of choosing suitable natural, climatic, soil and location quality conditions [13].

\subsubsection{Fire safety as a complex and specific high rise problem}

Building codes in all countries require increased fire safety conditions and fire-resistant loadbearing structures for tall buildings with specially designed details for load-bearing walls, fixing elements and columns, including the use of fire-resistant building materials.

Tall building structures require the presence of fire compartments, which divided the building in different sections, to limit the spread of fire. Special requirements are also imposed on the number of staircases as main escape routes in case of fire. According to Yu. Gluhovenko (the head of the Centre for Complex Security of the Central Research Institute of the Ministry of Construction of Russia), it is necessary to use fire lifts in high-rise buildings to evacuate people in emergency situations. If only stairs are used for this purpose, evacuation can last several hours. Such elevators should have specialized cabins and lift shafts [14].

\subsubsection{Ecological impact and use of natural lighting in high-rise buildings}

Of particular concern is the negative impact of high-rise buildings on the biosphere and human health $[15,16]$. According to insolation standards, high-rise buildings require certain distances between buildings of at least 100 meters, to minimize shading of lower floors even if all norms are observed [17]. In residential buildings, apartments on lower floors are uncomfortable, their economic quality and market value is low. According to modern building practice, ground floors are usually used for shops, commercial use or offices, to provide working places. Second and third floors also mostly lack natural light and are as a consequence of lower living quality. Neighbourhoods and the rights of neighbouring property owners of tall buildings may face violation of its rights for reasonable natural light and visual quality. In Bahrain, environmentalists have demanded, that all planned high-rise construction projects undergo during the planning permission phase an additional three-stage procedure for environmental, social and health assessment. They stated, "skyscrapers should be part of the social and physical urban environment, as well as to add to the value of the local community." Low air quality and floor heights lead to the syndrome of the "sick building" (overwork, convulsions, joint pain, dry and itchy skin, exhaustion, headaches, palpitation, cough, sore throat, inability to concentrate, hypersensitivity to smells and dyspnoea), causing a drop of productivity and higher fluctuation of people [18].

\subsubsection{Psychological discomfort of people in tall buildings}

For thousands of years people are living on earth and built houses on its ground, traditionally dwellings of 1-2 floors. People live nearly never under ground and high above grounds, because both underground structures and high-rise buildings can cause unpleasant living conditions and apprehensions. Modern technologies ensure the safety of living even in such places, but it must be taken into account that a considerable number of people have a fear of heights. According to safety standards, glazing of balconies and loggias is mandatory, 
however, glass does not create a sense of security. It is necessary to use railing (fencing) to reduce psychological discomfort. Above the 20th - 22nd floor open private outside areas like balconies, loggias and terraces are usually not realized, reducing the access of fresh air for rooms and inhabitants [19]. This problem can be partly solved by designing winter gardens to create psychological comfort and improve natural room ventilation. As studies show, people prefer to live in low-rise houses. In many cities, which became pioneers in the construction of high-rise buildings, a slowdown in the pace of tall building construction can be recognized. As an example for this can be mentioned the decreasing high-rise construction in Dubai, a world known city of dynamic high-rise building activity [5]. In various cities of Russia and abroad, there is also a clear tendency to abandon the construction of high-rise buildings

\subsubsection{Visual quality of high-rise buildings}

A person can feel discomfort not only on high floors, but also on the street next to high-rise buildings. Tall buildings and skyscrapers of low architectural quality can put psychological pressure on people, creating a sense of threat. People feel "tired", eye irritation, discontent with themselves and their environment in areas with monotonous architecture (economic high-rises). On the contrary, single high-rise buildings or a well-designed ensemble of towers has the potential of representing the city as a symbol (cathedral, iconic construction) and becoming a matter of pride ("and we are not worse, we also have our own skyscraper"). There are few such architectural masterpieces in the world, defining the "sensitiveness" of high-rise architecture design. The erection of high-rise buildings in city centres can violate the mental map of the urban inhabitants and create a sense of loss of their historic city [20].

\subsection{Sustainable standards as planning method for multifunctional high rise buildings}

The rapid growth of cities is a global tendency, which can be observed in nearly every cultural and political context today. Not only city centres are undergoing density transformations but potentially every kind of urban territory in medium and large size cities is exposed to economic development pressure to becoming a vertical city with manifold social, economical and technical challenges for inhabitants, the way, how people live together and the ecologic environment. High rise buildings and vertical city districts with groups of tall buildings are in most of the cases designed and built like low rise buildings but with a multiple number of floors, not considering the increased requirement of green spaces for recreation and communication and increased requirements for individual and public transport infrastructure. Successful cities were always open cities with socially orientated building typologies, balanced in functions and architectural styles, with enough open accessible green spaces and every day services.

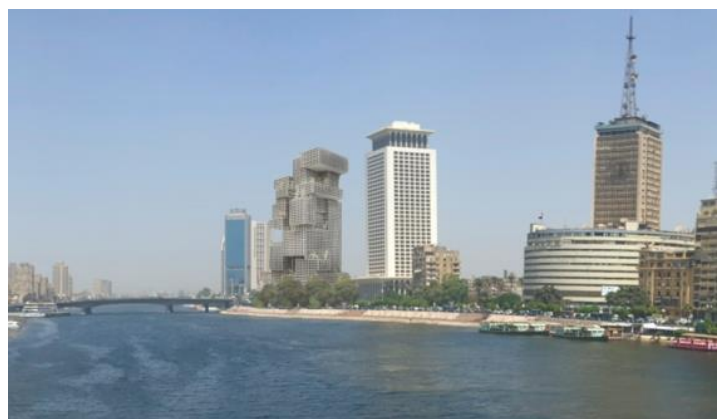

Fig.1. Vertical public high-rise development in Cairo, Prof. M. Eichner, R. Maher 2017 


\subsubsection{Sustainable standards for high rise structures}

Providing inhabitants of vertical building structures with a convenient and socially balanced living environment, using minimum energy and other natural resources and at the same time integrating the high rise structure into the urban context, represent the big challenges today. To promote social synergies and a conflict minimized urban atmosphere, facilities like urban district councils, childcare, community stations and public accessible recreation and communication spaces of sufficient areas should be provided. Modern sustainable building standards for housing buildings require from planners and developers to integrate within their development public accessible outside areas for communication, recreation, kids playing and youth activities as barrier-free landscape spaces. A sufficient size is around $10 \mathrm{~m}^{2}$ per person (synergy effects are allowed, for example the use of fire access roads or similar). In low rise housing districts, public spaces of significant size and high landscape quality are usually integrated in the form of squares, courtyards of pocket parks. Providing in high-rise buildings social valuable open spaces with pleasant and ecologic landscape design for different social groups and generations is widely neglected. One of the authors explored the advantages of an application of sustainable standards in multifunctional high-rise designs for central districts in downtown Cairo.
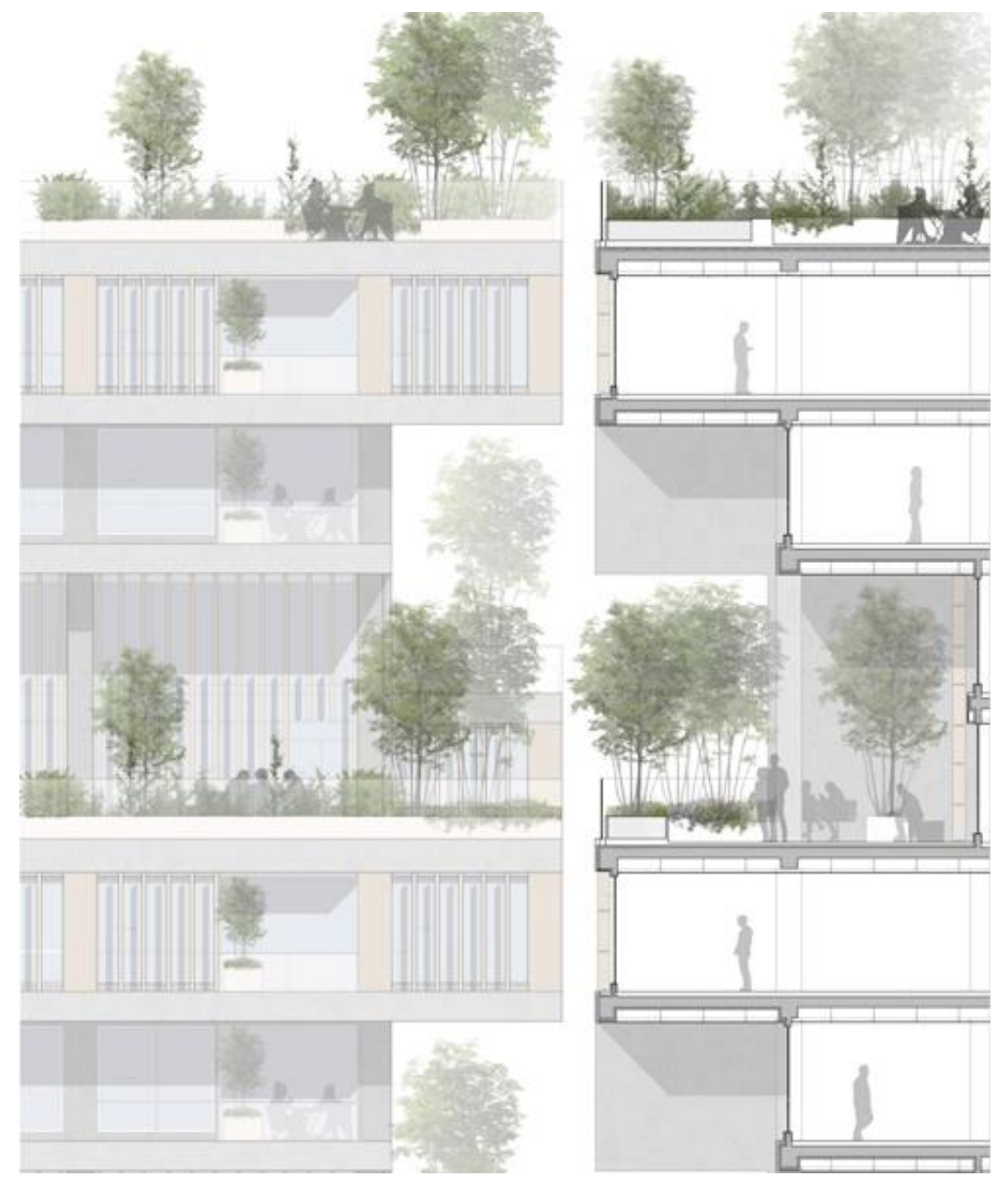

Fig.2. Vertical living city Cairo, detail section, Prof. M. Eichner, R. Anwar, GUC 2017 
The aim of this case study design project was to find out, whether it is possible today, within the economical and cultural context of the rapidly transforming Capital of Egypt to initiate a paradigm shift from socially isolated high-rise objects to socio-cultural and resource-efficient vertical cities structures, providing similar living quality like low rise housing districts. The question today is not whether high-rise buildings are preferable to low-rise buildings but how to design multi-storey buildings and districts, which meet all important sustainable and social criteria in an economical and balanced way.

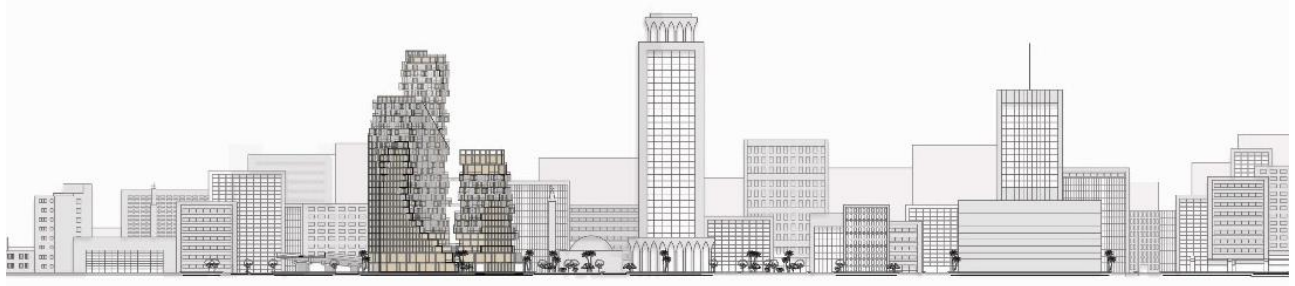

Fig.3. Vertical garden tower, Cairo, detail section, Prof. M. Eichner, H. Hamdy, GUC 2017

\subsection{Sociological surveys as indicator for needs of inhabitants of high rises}

City authorities should comprehensively study needs and opinions of their urban inhabitants prior to realization of high-rise buildings. Town planners should learn how residents feel while living in upper floors and physicians should study the physical and mental state of people, living or working in high-rise buildings. Such systematic studies are not conducted in Russia, but information on individual surveys can be found. The Internet based "Catalog of local home networks of the city of St. Petersburg" for example published the results of a sociological poll, how Moscow residents are thinking about skyscrapers and the possibility of living in them. The results of the study showed, that a significant part of Muscovites would refuse to live in a residential high-rise building. Out of the total number of respondents, $58 \%$ answered negatively, the remaining $42 \%$ expressed their desire to live in a high-rise building. The interviewed Muscovites, who did not agree to live in high-rise apartment buildings, explained their fundamental refusal for living in skyscrapers with fear of height, possible problems with technical building systems and elevators. In addition, most of them are confident, that there is a greater likelihood of accidents and terrorist attacks in buildings of this type. This allows to conclude, that low-rise buildings are preferred by many people. The smaller part of the people, who participated in the survey in Moscow (42\% of respondents) like modern high-rise buildings. They relate them to beauty and comfort and consider them as the solution of the housing shortage problem in the capital. In addition, the representatives of this group mentioned the advantage of apartment layouts in skyscrapers and the availability of garages. They also noted the opportunity to enjoy the beautiful scenery and get the full spectre of emotions [21]. These results show, that Muscovites differ in their opinions with a significant number of people in Moscow, assessing life in a high-rise building positively.

The authors of the article conducted a sociological survey at the Moscow State University of Civil Engineering in November 2017, asking questions about the influence of high-rise buildings on the urban ecology. Sixty students were interviewed: $66 \%$ of the respondents answered, that high-rise construction negatively affects the environment. $6 \%$ of the respondents concluded, that the impact of Russia's contemporary construction industry is even devastating for the environment. At the same time, students said, that they do not have enough environmental knowledge to judge professionally the impact of high-rise buildings 
on the ecology of urban territory. $28.3 \%$ of respondents do not know what "green standards" or "sustainable construction standards" are. The results of this survey indicate that in Russia to date little attention is paid to the environmental education of engineers, planners and builders. Students lack knowledge about modern eco-sustainable technologies for the construction of unique buildings and structures.

\section{Conclusions}

The study conducted by the authors of the article allows concluding, that the socio-ecological impact of high-rise buildings has not been sufficiently studied. On the one hand, their negative impact on the biosphere and people is obvious. On the other hand, there are social groups interested in high-rise construction, among which are, city authorities, developers, architects and a part of the urban population. Each of these groups has its own interests: economic, financial, urban development, creative or political. The opinion of the authors of the article: despite the slowdown in the tendency of high-rise construction in some countries, it will continue and even grow. It is impossible and not useful to build barriers for a creative search of new construction technologies for tall buildings, innovative high-rise development strategies and expressions skyscraper architecture. However, the interests of the biosphere, mankind and society should become the main goal of high-rise construction. Each project should be correlated with people's needs, a humanitarian balance and the low impact on the biosphere. This requires a wider and more creative application of sustainable planning solutions and technologies during the design and construction of high-rise buildings, briefly presented in this article with projects of Professor M. Eichner.

\section{References}

1. G. Binder, Tall buildings of Europe, the Middle East and Africa (Sydney: Images Publishing, 2006).

2. T.G Maklakova, High-rise buildings. Urban planning and architectural-constructive design problems. (ASV, Moscow, 2008).

3. URL: https://www.golosagorodov.info/istoricheskaja-spravka/goroda/skolkonaseleniya-zhivet-v-gorodakh-sovremennoy-rossii.html

4. Evaluation news. Moscow: the cost per square meter of land. URL: https://proocenka.ru/otrasl-news/1476-moskva-stoimost-kvadratnogo-metra-zemli.

5. A. V. Korotich, Akademicheskij Vestnik UralNIIproektRAASN 2, 51-55 (2016).

6. A. V. Korotich, Akademicheskij Vestnik UralNIIproektRAASN 3,43-46 (2011).

7. K. Fender, Asia \& Australasia: A Selection of Written Works on the World's Tall Building Forefront, Conference Proceeding, 154-163 (2015).

8. C. Stalker, Beyond the Podium: Urban Spaces for Tall Buildings in a Subtropical City. Asia \& Australasia: A Selection of Written Works on the World's Tall Building Forefront, 172-183 (2015).

9. K. Wan, G. Cheung \& V. Cheng, CTBUH Journal, Issue III, 20-25 (2015).

10. URL : http://refy.ru/8/13532-obespechenie-kompleksnoy-bezopasnosti-pristroitelstve-vysotnyh-zdaniy.html

11. URL: https://www.abok.ru/for_spec/articles.php?nid=1387

12. URL: http://www.maconnc.org/MORATORIUM\%20ON\%20\%20HIGHRise $\% 20$ construction\%20Adopted.pdf. 
13. C. Kopczynski \& M. Whiteley, CTBUH Journal, Issue III, 20-26, (2016).

14. URL: www.https//andexpert.ru

15. URL: http://ecom.su/city_building/index.php?id=969;

16. Ecological threat threatens Almaty due to high-rise construction URL: https://www.kn.kz/news/47984/

17. URL: http://global.ctbuh.org/resources/papers/download/2404-integrated-andintelligent-buildings-an-imperative-to-people-the-planet-and-the-bottom-line.pdf

18. URL : http://www.gulf-dailynews.com/Story.asp? Article=199234\&Sn=BNEW\&IssueID=30232.

19. URL: https://www.abok.ru/for_spec/articles.php?nid=2444

20. URL : http://www.international.icomos.org/risk/2006/istanbul2006.htm

21. The popularity of skyscrapers among Muscovites: a sociological survey. URL: http://spb-nets.ru/articles/na.php?id=22 